\title{
Investigation of Inhibitory Activity and Bioactive Compounds of Piper nigrum Seeds on Selected Human Pathogens
}

\author{
Renu Chauhan, Ekta Chaudhary and Neha Chauhan*
}

\author{
Division of Life science, Shri Guru Ram Rai Institute of Technology and Science, \\ Dehradun, Uttarakhand, India \\ *Corresponding author
}

\section{A B S T R A C T}

\begin{tabular}{|c|c|}
\hline Keywords & \multirow{4}{*}{$\begin{array}{l}\text { With the increasing incidents of new and remerging infectious diseases, discovery } \\
\text { and urgent need of new microbial compounds having diverse chemical structures } \\
\text { and novel mechanism have also been increased. The study focused on determining } \\
\text { the antibacterial properties of } P \text {. nigrum against pathogenic bacteria and analyzing } \\
\text { the phytochemical constituents responsible for these medicinal activities. The } \\
\text { plant seeds were collected, shade dried and powdered and subjected to extraction } \\
\text { by Cold maceration in various solvents. The extracts were used to determine the } \\
\text { antibacterial activity by agar well diffusion method and MIC assay. The } \\
\text { phytochemistry was also analyzed. Data obtained showed that the ethyl acetate } \\
\text { extract was found to be most effective against the selected bacterial cultures. } \\
\text { Phenolic content was found as a major phytochemical constituent. On the basis of } \\
\text { the Data obtained it is clear that plant extracts can be used as effective herbal cure } \\
\text { against human pathogens. }\end{array}$} \\
\hline $\begin{array}{l}\text { n, } \\
\text { well }\end{array}$ & \\
\hline Artic & \\
\hline 10 July $201 /$ & \\
\hline
\end{tabular}

\section{Introduction}

Piper nigrum is well known for its bactericidal, cytotoxic and pharmacological benefits. Medicinal plants are various plants thought by some to have medicinal properties, but few plants or their phytochemical constituents have been proven by rigorous science to have medicinal effects. Phytochemicals are non-nutritive plant chemicals that have protective or disease preventive properties (Ganesh et al., 2014).Piper nigrum is originally a native to Southwestern India, also known as Malabar Coast. This region is comprised of lush tropical evergreen forests that are very humid and mountainous. Black pepper is now also cultivated in Cochin-China, East and West Indies, Malay Peninsula, Malay Archipelago, Siam, Malabar and other tropical areas around the world. Plant is perennial, woody climber having height up to $10 \mathrm{~m}$ or more. Leaves are alternately arranged and almond shaped with tapered tip. They are dark green and shiny above but paler green below. Length of leaf petiole is higher in runner shoots as compared to lateral. Varieties having lower leaf petiole length at the top and increased petiole length at the bottom, both in runner as well as in lateral branches are considered to be ideal for harvesting maximum light. A black pepper plant mostly has monoecious and bisexual 
flowers. Cluster of flowers grow on a flowering stalk called spikes. Flowers are whitish to yellow-green in color. About 50150 flowers are present on a single spike. The fruit of black pepper is spicy and aromatic. They are round and berry-like.

Medicinal plants have been used for years for the preparation of traditional medicines from their natural products which possess antimicrobial activities and thus can cure different diseases (Sharma et al., 2013 and Yang et al., 2009). Plants having medicinal and spice properties are renewable raw material and are of great economic importance. Dried substances of plants or vegetables, which can be whole, broken or in ground form, having fragrant, aromatic or pungent properties can be defined as Spices. Spices contribute in seasoning and flavouring food and beverages rather than providing nutrition (Draughon, 2004). Plant parts that serves as spices includes leaves (coriander, mint), flower (clove), bulbs (garlic, onion), stem (cinnamon), rhizomes (ginger, turmeric) and fruits (red chili, black pepper) (Cown, 1999). It was estimated that majority of the world population (about $80 \%$ ), to meet their demand, depends on medicines that are derived from plant products (Haq, 2004). One of the main reason of the wide use of plant based products or plant extracts as food preservatives against food borne pathogens is the presence of antibacterial and antifungal activities. These activities are due to the presence of some compounds like isoflavones, anthocyanins and flavonoids (Cown, 1999).

Pepper is native to India and since ancient times has been a prized spice. Due to its antimicrobial property, pepper had been used for the treatment of several diseases like congestion, fever, paralytic, arthritic disorder, vertigo, chronic indigestion, colon toxins, obesity, sinusitis and even diarrohea and cholera (Saranraj et al., 2014). In plants, the capability of production of definite physiological action on disease causing organisms is due to the presence of secondary metablic compounds such as flavonoids, steroids, resins, alkaloids, steroids, tannins, phenol compounds and fatty acids.

For the discovery of new drugs that are effective in treating several diseases, the screening of plant extracts has been of great interest to scientist (Mahesh et al., 2008).Antibacterial effects of $P$. nigrum, ethyl acetate, methanolic and aqueous extracts have been evaluated against some Gram positive and Gram negative bacteria responsible for causing food poisoning and food borne infections by Costa et al., 2010 and Lund et al., 2011 and selected microbes were Escherichia coli, Salmonella typhi, Pseudomonas aeruginosa, Staphylococcus aureus and Bacillus subtilis. Phytotherapeutics as an alternative tool can be used as microbial agents to control microbial infections in the resistant cases as they are cost-effective and environmentally safe (Schelz et al., 2010).

Thus, for the development of novel chemotherapeutic agents, medicinal plants can be utilized as a potential reservoir (Yang et al., 2009). In our present study, medicinal properties of $P$. nigrum seed extracts were exploited against various infections caused by Gram positive and gram negative bacteria and phytochemical analysis was also done to find out the active ingredients responsible for the antibacterial activity.

\section{Materials and Methods}

\section{Plant material and extraction}

The dried mature seeds of Piper nigrum purchased from local market of Dehradun, India. Twenty five grams of seeds powder 
was taken and soaked in $250 \mathrm{ml}$ of organic solvents (Ethyl acetate, Methanol) and water for extraction using Cold Maceration method (Akhtar et al., 2014). All the extracts were made solvent free and concentrated using rotary evaporator and preserved at $4{ }^{\circ} \mathrm{C}$ in airtight bottle until further use.

\section{Chemicals and Reagents}

The chemicals and reagents used for the study are of pure grade. Ethyl acetate, Methanol, $20 \%$ Acetic acid, Conc. Ammonium hydroxide, Folin- Ciocalteacee reagent, Dil. Folins-phenol reagent (1:1 ratio with water), Sodium carbonate (20\%), Gallic acid, Sodium nitrate (5\%), Aluminum chloride (10\%), Sodium hydroxide (4\%), Polyvinyl polypyrrolidone, Vanillin reagent $(800 \mathrm{gm}$ of vanillin in $10 \mathrm{ml}$ of $99.5 \%$ ethanol), Sulphuric acid (72\%), Metaphosphoric acid (1\%), 2,6dichloroindophenol sodium salt hydrate, LAscorbic acid and Distilled water.

\section{Microorganisms}

Five different microorganisms representing Gram-positive and Gram-negative bacteria were used in this study. The two grampositive bacteria were- Bacillus subtilis and Staphylococcus aureus while the three gramnegative bacteria were-Escherichia coli, Pseudomonas and Salmonella typhi.

\section{Antimicrobial activity}

Antibacterial activities of all the extracts (Ethyl acetate, Methanol, Aqueous) of $P$. nigrum were determined by agar well diffusion method (Chauhan, Neha. et al., 2012). The extracts were dissolved in DMSO (dimethylsulphoxide) to obtain $0.5 \mathrm{mg} / 100 \mu \mathrm{l}$ and $1 \mathrm{mg} / 100 \mu \mathrm{l}$ concentration. Commercial antibiotic (Gentamicin) and DMSO was used as positive and negative control respectively. The test was performed in triplicates and the final results were presented as the mean zone of inhibition.

\section{Broth dilution MIC tests (NCCLS, 1993)}

This test was done to check the zone of inhibition which was minimum. This process is named as macro broth dilution assay. Muller- Hinton broth diluents was taken and 2 -fold serial dilutions of all extracts were prepared in the well on the basis of result obtained from agar well diffusion method.

Gentamicin and DMSO are positive and negative control respectively $20 \mu \mathrm{l}$ of test culture at concentration $\left(5 \times 10^{5} \mathrm{cfu} / \mathrm{ml}\right)$ was inoculated and plates were incubated for $24 \mathrm{~h}$ at $37^{\circ} \mathrm{C}$.

Plate with minimum growth was taken and concentration is noted as minimum inhibitory concentration. Another value minimum bacterial count was calculated by spreading $20 \mu 1$ of MIC test broth on a new plate incubating for $18-24 \mathrm{~h}$ at $37^{\circ} \mathrm{C}$. Dilution of plates showing no single bacterial growth was taken as MBC concentration. Triplicates were used to perform. Test and mean MIC and MBC value were calculated and noted.

\section{Phytochemical analysis}

\section{Qualitative analysis}

Qualitative analysis was done in accordance to (Sharma et al., 2014).

\section{Test for glycosides (Sulphuric acid test)}

To $1 \mathrm{ml}$ of plant extract, few drops of sulphuric acids were added and the mixture was allowed to stand for few minutes. Presence of glycosides was confirmed by the formation of Reddish precipitate. 


\section{Test for carbohydrates (Molisch's test)}

To $1 \mathrm{ml}$ of extract, $2 \mathrm{ml}$ of Molisch's Reagent was added. Now to this mixture, $2 \mathrm{ml}$ conc. sulphuric acid was added along the sides of the test tube. Presence of carbohydrates was confirmed by the formation of reddish violet ring at the junction of two liquids.

\section{Test for flavonoids (Aqueous test)}

To $1 \mathrm{ml}$ of plant extract, add $1 \mathrm{ml}$ of aqueous $\mathrm{NaOH}$. Yellow colour formation showed the presence of flavonoids.

\section{Test for saponins (Aqueous test)}

To $1 \mathrm{ml}$ of extract add $5 \mathrm{ml}$ water and shake well in a test tube shaker. Lather formation shows the presence of saponins.

\section{Test for tannins (Ferric chloride test)}

To $1 \mathrm{ml}$ of plant extract add $1 \mathrm{ml}$ of ferric chloride. Formation of greenish black colour confirmed the presence of tannins.

\section{Test for alkaloids (Dragondroff's reagent)}

To $1 \mathrm{ml}$ of plant extract add 5-6 drops of Dragondroff's reagent. Formation of creamish/ brownish-red/ orange precipitate confirmed the presence of alkaloids.

\section{Quantitative analysis}

Quantitative tests were used to detect the presence of phenolics, saponins, flavonoids and ascorbic acid (Sharma et al., 2014)

\section{Test for total phenolics content}

The total phenolics content of $P$. nigrum was estimated using Folin- Ciocalteace reagent by the method of Sidduraju and Becker. About 20 microgram of leaf and root extracts was taken separately and it was made up to $1 \mathrm{ml}$ with distilled water. Then 500 microliter of diluted Folins-phenol reagent (1:1 ratio with water) and $2.5 \mathrm{ml}$ of sodium carbonate $\mathrm{Na} 2 \mathrm{CO} 3(20 \%)$ were added. The mixture was shaken well and incubated in dark condition for $40 \mathrm{~min}$. for the development of colour. After incubation, the absorbance was measured at $725 \mathrm{~nm}$. A calibration curve of Gallic acid was constructed and linearity was obtained in the range of 10-50microgram $/ \mathrm{ml}$. The total phenolics content in the plant extracts were expressed as $\mathrm{mg}$ of Gallic acid equivalent (mg GAE/g extract) by using the standard curve.

\section{Test for Flavonoids content}

The total flavonoids content was estimated using the procedure described by Zhishen et al., A total of $1 \mathrm{ml}$ of plant extracts were diluted with 200 microliter of distilled water separately followed by the addition of 150 microliter of sodium nitrite $(5 \%)$ solution. This mixture was incubated for $5 \mathrm{~min}$ and then 150 microliter of aluminium chloride $(10 \%)$ solution was added and allowed to stand for $6 \mathrm{~min}$. Then $2 \mathrm{ml}$ of sodium hydroxide $(4 \%)$ solution was added and made up to $5 \mathrm{ml}$ with distilled water. The mixture was shaken well and left it for $15 \mathrm{~min}$ at room temperature. The absorbance was measured at $510 \mathrm{~nm}$. Appearance of pink colour showed the presence of flavonoids content. The total flavonoids content was expressed as rutin equivalent $\mathrm{mg} \mathrm{RE} / \mathrm{g}$ extract on a dry weight basis using the standard curve.

\section{Test for total saponins content}

Estimation of total saponins content was determined by the method described by Makkaret. All based on Vallin-sulphuric acid colorimetric reaction with some modifications. About 50 microliter of plant 
extract was added with 250 microliter of Vanillin reagent $(800 \mathrm{mg}$ of vanillin in $10 \mathrm{ml}$ of $99.5 \%$ ethanol) was added. Then $2.5 \mathrm{ml}$ of $72 \%$ sulphuric acid was added and it was mixed well. This solution was kept in a water bath at $60 \mathrm{C}$ for $10 \mathrm{~min}$. After $10 \mathrm{~min}$, it was cooled in ice cold water and the absorbance was read at $544 \mathrm{~nm}$. The values were expressed as diosgenin equivalent (mg DE/g extract) derived from a standard curve.

\section{Results and Discussion}

\section{Antimicrobial activity}

The antibacterial activity of the plants was evaluated using agar well diffusion method. All the seed extracts of $P$. nigrum showed the antibacterial activity against the selected microbes. Gentamicin used as a positive control showed the maximum ZOI against B1 for both the concentrations of $0.5 \mathrm{mg} / 100 \mu \mathrm{l}$ and $1 \mathrm{mg} / 100 \mu \mathrm{l}$ i.e. $31 \mathrm{~mm}$ and $35 \mathrm{~mm}$ respectively followed by B3, B2, B4 and B5. For $0.5 \mathrm{mg} / 100 \mu 1$ concentration of $\mathrm{E} 1$ extract, $\mathrm{B} 1$ and $\mathrm{B} 4$ showed the maximum ZOI i.e. $21 \mathrm{~mm}$ followed by B2 (ZOI- $17 \mathrm{~mm})$, B5 (ZOI-16mm) and the minimum zone of inhibition was of $\mathrm{B} 3$ i.e. $14 \mathrm{~mm}$. For $1 \mathrm{mg} / 100 \mu$ lconcentration of E1 extract the most susceptible bacteria was B1 with ZOI of $24 \mathrm{~mm}$. It was followed by B4 (ZOI-21mm), B2 (ZOI-19mm), B5 (ZOI-18mm) and the B3 which was the least susceptible bacteria having zone of inhibition $16 \mathrm{~mm}$. For $0.5 / 100 \mu \mathrm{lmg}$ concentration of E2 extract, B4 and $\mathrm{B} 5$ showed the maximum $\mathrm{ZOI}$ i.e. $18 \mathrm{~mm}$ and $14 \mathrm{~mm}$ respectively. $\mathrm{B} 3$ have the $\mathrm{ZOI}$ of $10 \mathrm{~mm}$ and the $\mathrm{B} 1$ and $\mathrm{B} 2$ have the same ZOI i.e. $8 \mathrm{~mm}$ which makes them least susceptible. For $1 \mathrm{mg} / 100 \mu$ lconcentration of E2 extract, B1, B2 and B3 showed least susceptibility having zone of inhibition of $9 \mathrm{~mm}, 9 \mathrm{~mm}$ and $12 \mathrm{~mm}$ respectively. The highest susceptibility was observed in B4 having zone of inhibition of $22 \mathrm{~mm}$ followed by B5 having zone of inhibition of $16 \mathrm{~mm}$. This shows that the B4 is the most susceptible while the B2 and B1 are the least susceptible for E2 extract. For $0.5 \mathrm{mg} / 100 \mu 1$ concentration of E3 extract, B1 and $\mathrm{B} 5$ have maximum zone of inhibition i.e. $8 \mathrm{~mm}$ followed by B2 and B4 which have zone of inhibition of $7 \mathrm{~mm}$ and $\mathrm{B} 3$ have the least zone of inhibition i.e. $6 \mathrm{~mm}$. For $1 \mathrm{mg} / 100 \mu$ lconcentration, the maximum zone of inhibition was observed for B1 i.e. $10 \mathrm{~mm}$ followed by B4 having zone of inhibition of $9 \mathrm{~mm}$. The zone of inhibition for B2, B3 and $\mathrm{B} 5$ is equal i.e. $8 \mathrm{~mm}$. So it shows that the $\mathrm{B} 1$ is the most susceptible bacteria for the E3 extract of seeds of $P$. nigrum. The results obtained were tabulated in tables 1, 2, 3, 4 and 5. The extracts showing high efficacy against selected pathogens were subjected to minimum inhibitory concentration (MIC) assay by two-fold serial dilution method (2:2)

\section{Qualitative analysis}

The various plant extracts of $P$. nigrum were phytochemically assessed using qualitative as well as quantitative methods. Phytochemical analysis of $P$. nigrum ethanolic extract showed the presence of Glycosides, carbohydrates, flavonoids, saponins, tannins and alkaloids. Methanolic extract of $P$. nigrum also showed the presence of glycosides, carbohydrates, flavonoids, saponins, tannins and alkaloids. Aqueous extract of $P$. nigrum showed the presence of glycosides, carbohydrates, flavonoids, saponins, tannins and alkaloids. Results are tabulated in table 5 .

\section{Quantitative analysis}

The phytochemical assessment of various plant extracts was done using quantitative methods. The phenolic content was found to be highest in E1 extract i.e. 0.591 followed by $\mathrm{E} 3$ i.e. 0.556 and then the $\mathrm{E} 2$ extract i.e. 0.515 . The content of saponins was highest in 
E3 extract i.e. 0.044.E2 extract showed the highest flavonoid content i.e. 0.015.The saponin content was found to be highest in E3 (0.044) extract of $P$. nigrum followed by E2 (0.035) and then E1 (0.025). The flavonoid content was present highest in E2 extract (0.015) followed by E1 (0.009) and E3 (0.007). The results of quantitative screening of different extracts have been tabulated in table 6 and figure 2 .

MIC

MIC is the lowest concentration of the test sample or drug at which it shows the highest inhibitory activity against microorganisms. The extracts showing high efficacy against microorganisms were subjected to minimum inhibitory concentration (MIC) assay by twofold serial dilution method (2:2) (Florey et al., 1989 and Drummond et al., 2000). From the data obtained it was observed that the MIC value ranged from $0.0156-0.625 \mathrm{mg} / \mathrm{ml}$. To determine whether an extract is bactericidal $(\mathrm{MIC} / \mathrm{MBC}<4)$ or bacteriostatic $(\mathrm{MIC} / \mathrm{MBC}$ $>4$ ) in nature MIC Index (MIC/MBC) was performed. The E1 extract showed the lowest concentration of MIC for B2 i.e. $0.625 \mathrm{mg} / \mathrm{ml}$. MIC concentration for E2 extract was found to be lowest for B3 i.e. $0.125 \mathrm{mg} / \mathrm{ml}$ and the E3 extract showed the same MIC value for all the selected microbes i.e. $0.25 \mathrm{mg} / \mathrm{ml}$ (Fig. 1)

Fig.1 Represents antibacterial activity of $P$. nigrum E1 extract against various bacterial cultures

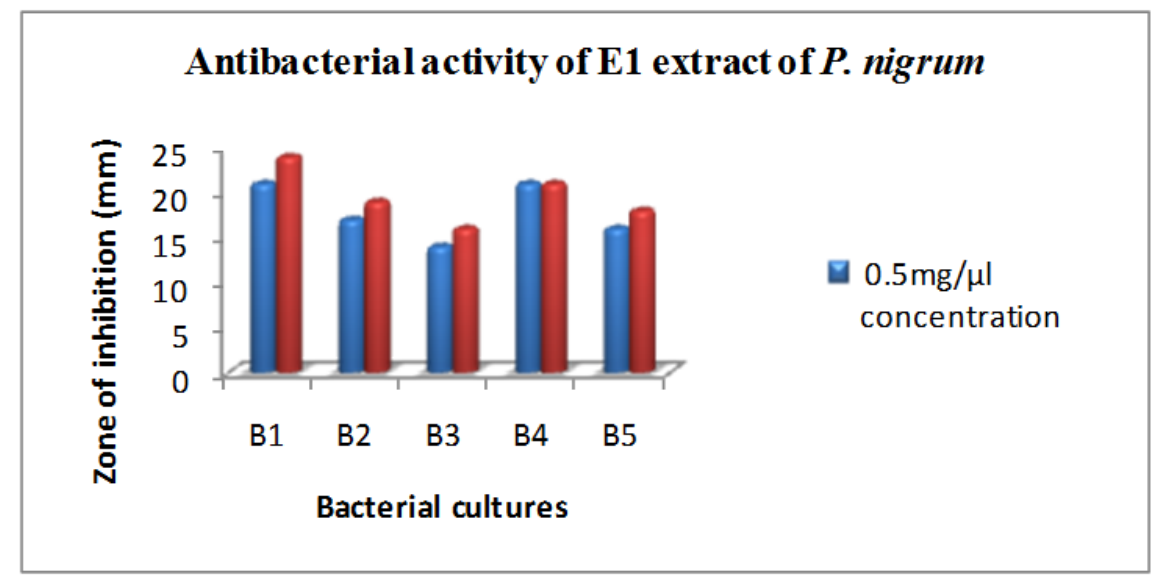

Fig.2 Represents the concentration phytochemicals in various extracts of P. nigrum

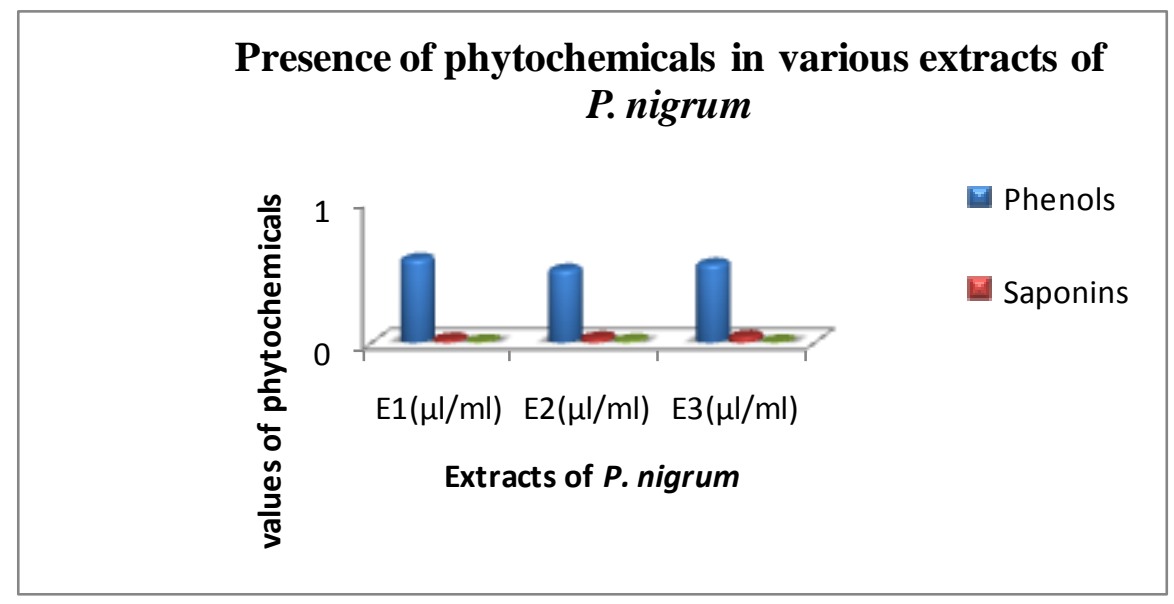


Table.1 The yield and physical properties of Piper nigrum extracts

\begin{tabular}{|c|l|c|l|l|}
\hline S. No. & \multicolumn{1}{|c|}{ Solvent Used } & Yield $\mathbf{( g / 2 5 0 m l )}$ & \multicolumn{1}{c|}{ Colour } & \multicolumn{1}{c|}{ State } \\
\hline 1. & Ethyl Acetate (E1) & 3.41 & Blackish brown & Viscous \\
\hline 2. & Methanol (E2) & 1.64 & Blackish brown & Viscous \\
\hline 3. & Water $(\mathbf{E 3 )}$ & 2.12 & Brownish & Solid \\
\hline
\end{tabular}

Table.2 Antibacterial activity of Gentamicin

\begin{tabular}{|c|c|c|c|}
\hline S. No. & Bacterial cultures & ZOI (0.5mg Concentration) & ZOI (1mg Concentration) \\
\hline 1. & B1 & $31 \mathrm{~mm}$ & $35 \mathrm{~mm}$ \\
\hline 2. & B2 & $26 \mathrm{~mm}$ & $30 \mathrm{~mm}$ \\
\hline 3. & B3 & $27 \mathrm{~mm}$ & $32 \mathrm{~mm}$ \\
\hline 4. & B4 & $24 \mathrm{~mm}$ & $28 \mathrm{~mm}$ \\
\hline 5. & B5 & $22 \mathrm{~mm}$ & $27 \mathrm{~mm}$ \\
\hline
\end{tabular}

Table.3 Antibacterial activity of $P$. nigrum E1 extract

\begin{tabular}{|c|c|c|c|}
\hline S. No. & Bacterial cultures & ZOI (0.5mg Concentration) & ZOI (1mg Concentration) \\
\hline 1. & B1 & $21 \mathrm{~mm}$ & $24 \mathrm{~mm}$ \\
\hline 2. & B2 & $17 \mathrm{~mm}$ & $19 \mathrm{~mm}$ \\
\hline 3. & B3 & $14 \mathrm{~mm}$ & $16 \mathrm{~mm}$ \\
\hline $\mathbf{4 .}$ & B4 & $21 \mathrm{~mm}$ & $21 \mathrm{~mm}$ \\
\hline 5. & B5 & $16 \mathrm{~mm}$ & $18 \mathrm{~mm}$ \\
\hline
\end{tabular}

Table.4 Antibacterial activity of $P$. nigrum E2 extract

\begin{tabular}{|c|c|c|c|}
\hline S. No. & Bacterial cultures & ZOI (0.5mg Concentration) & ZOI (1mg Concentration) \\
\hline 1. & B1 & $8 \mathrm{~mm}$ & $10 \mathrm{~mm}$ \\
\hline 2. & B2 & $8 \mathrm{~mm}$ & $10 \mathrm{~mm}$ \\
\hline 3. & B3 & $10 \mathrm{~mm}$ & $12 \mathrm{~mm}$ \\
\hline $\mathbf{4 .}$ & B4 & $18 \mathrm{~mm}$ & $22 \mathrm{~mm}$ \\
\hline $\mathbf{5 .}$ & B5 & $14 \mathrm{~mm}$ & $16 \mathrm{~mm}$ \\
\hline
\end{tabular}

Table.5 Antibacterial activity of $P$. nigrum E3 extract

\begin{tabular}{|c|c|c|c|}
\hline S. No. & Bacterial cultures & ZOI (0.5mg Concentration) & ZOI (1mg Concentration) \\
\hline $\mathbf{1 .}$ & B1 & $8 \mathrm{~mm}$ & $10 \mathrm{~mm}$ \\
\hline $\mathbf{2 .}$ & B2 & $7 \mathrm{~mm}$ & $8 \mathrm{~mm}$ \\
\hline $\mathbf{3 .}$ & $\mathbf{B 3}$ & $6 \mathrm{~mm}$ & $8 \mathrm{~mm}$ \\
\hline $\mathbf{4 .}$ & $\mathbf{B 4}$ & $7 \mathrm{~mm}$ & $9 \mathrm{~mm}$ \\
\hline $\mathbf{5 .}$ & $\mathbf{B 5}$ & $8 \mathrm{~mm}$ & $10 \mathrm{~mm}$ \\
\hline
\end{tabular}


Table.6 The MIC, MBC and MIC Index values of E1 extract against different pathogens

\begin{tabular}{|l|l|l|l|l|l|l|l|}
\hline Organisms & $\begin{array}{l}\text { Range } \\
(\mathbf{m g} / \mathbf{m l})\end{array}$ & $\begin{array}{l}\text { MIC } \\
\text { (control) } \\
(\mathbf{m g} / \mathbf{m l})\end{array}$ & $\begin{array}{l}\text { MBC } \\
\text { (control) } \\
(\mathbf{m g} / \mathbf{m l})\end{array}$ & $\begin{array}{l}\text { MIC } \\
(\mathbf{e x t r a c t )} \\
(\mathbf{m g} / \mathbf{m l})\end{array}$ & $\begin{array}{l}\text { MBC } \\
(\mathbf{e x t r a c t}) \\
(\mathbf{m g} / \mathbf{m l})\end{array}$ & $\begin{array}{l}\text { MIC } \\
\text { Index } \\
\text { (control) }\end{array}$ & $\begin{array}{l}\text { MIC } \\
\text { Index } \\
\text { (extract) }\end{array}$ \\
\hline B1 & $0.5-0.0156$ & 0.0156 & 0.0312 & 0.125 & 0.25 & 2 & 2 \\
\hline B2 & $0.5-0.0156$ & 0.0156 & 0.0312 & 0.625 & 0.125 & 2 & 0.2 \\
\hline B3 & $0.5-0.0156$ & 0.0156 & 0.0312 & 0.125 & 0.25 & 2 & 2 \\
\hline B4 & $0.5-0.0156$ & 0.0156 & 0.0312 & 0.125 & 0.25 & 2 & 2 \\
\hline B5 & $0.5-0.0156$ & 0.0156 & 0.0312 & 0.25 & 0.5 & 2 & 2 \\
\hline
\end{tabular}

Table.7 The MIC, MBC and MIC Index values of E2 extract against different pathogens

\begin{tabular}{|l|l|l|l|l|l|l|l|}
\hline Organisms & $\begin{array}{l}\text { Range } \\
(\mathbf{m g} / \mathbf{m l})\end{array}$ & $\begin{array}{l}\text { MIC } \\
\text { (control) } \\
(\mathbf{m g} / \mathbf{m l})\end{array}$ & $\begin{array}{l}\text { MBC } \\
\text { (control) } \\
(\mathbf{m g} / \mathbf{m l})\end{array}$ & $\begin{array}{l}\text { MIC } \\
\text { (extract) } \\
\text { (mg/ml) }\end{array}$ & $\begin{array}{l}\text { MBC } \\
\text { (extract) } \\
(\mathbf{m g} / \mathbf{m l})\end{array}$ & $\begin{array}{l}\text { MIC } \\
\text { Index } \\
\text { (control) }\end{array}$ & $\begin{array}{l}\text { MIC } \\
\text { Index } \\
\text { (extract) }\end{array}$ \\
\hline B1 & $0.5-0.0156$ & 0.0156 & 0.0312 & 0.25 & 0.5 & 2 & 2 \\
\hline B2 & $0.5-0.0156$ & 0.0156 & 0.0312 & 0.25 & 0.5 & 2 & 2 \\
\hline B3 & $0.5-0.0156$ & 0.0156 & 0.0312 & 0.125 & 0.25 & 2 & 2 \\
\hline B4 & $0.5-0.0156$ & 0.0156 & 0.0312 & 0.25 & 0.5 & 2 & 2 \\
\hline B5 & $0.5-0.0156$ & 0.0156 & 0.0312 & 0.25 & 0.5 & 2 & 2 \\
\hline
\end{tabular}

Table.8 The MIC, MBC and MIC Index values of E3 extract against different pathogens

\begin{tabular}{|l|l|l|l|l|l|l|l|}
\hline Organisms & $\begin{array}{l}\text { Range } \\
(\mathbf{m g} / \mathbf{m l})\end{array}$ & $\begin{array}{l}\text { MIC } \\
\text { (control) } \\
(\mathbf{m g} / \mathbf{m l})\end{array}$ & $\begin{array}{l}\text { MBC } \\
\text { (control) } \\
(\mathbf{m g} / \mathbf{m l})\end{array}$ & $\begin{array}{l}\text { MIC } \\
\text { (extract) } \\
\text { (mg/ml) }\end{array}$ & $\begin{array}{l}\text { MBC } \\
\text { (extract) } \\
(\mathbf{m g} / \mathbf{m l})\end{array}$ & $\begin{array}{l}\text { MIC } \\
\text { Index } \\
\text { (control) }\end{array}$ & $\begin{array}{l}\text { MIC } \\
\text { Index } \\
\text { (extract) }\end{array}$ \\
\hline B1 & $0.5-0.0156$ & 0.0156 & 0.0312 & 0.25 & 0.5 & 2 & 2 \\
\hline B2 & $0.5-0.0156$ & 0.0156 & 0.0312 & 0.25 & 0.5 & 2 & 2 \\
\hline B3 & $0.5-0.0156$ & 0.0156 & 0.0312 & 0.25 & 0.5 & 2 & 2 \\
\hline B4 & $0.5-0.0156$ & 0.0156 & 0.0312 & 0.25 & 0.5 & 2 & 2 \\
\hline B5 & $0.5-0.0156$ & 0.0156 & 0.0312 & 0.25 & 0.5 & 2 & 2 \\
\hline
\end{tabular}

Table.9 Represents the presence of different phytochemicals in various extracts of $P$.nigrum

\begin{tabular}{|c|c|c|c|c|}
\hline S. & & \multicolumn{3}{|c|}{ Piper nigrum } \\
\cline { 3 - 5 } No. & Phytochemicals & E1 extract & E2 extract & E3 extract \\
\hline $\mathbf{1}$ & Glycosides & Present & Present & Present \\
\hline $\mathbf{2}$ & Carbohydrates & Present & Present & Present \\
\hline $\mathbf{3}$ & Flavonoids & Present & Present & Present \\
\hline $\mathbf{4}$ & Saponins & Present & Present & Present \\
\hline $\mathbf{5}$ & Tannins & Present & Present & Present \\
\hline $\mathbf{6}$ & Alkaloids & Present & Present & Present \\
\hline
\end{tabular}

Table.10 Quantitative analysis of $P$. nigrumvarious extracts

\begin{tabular}{|c|c|c|c|}
\hline \multirow{2}{*}{ Extracts } & \multicolumn{3}{|c|}{ Phytochemicals } \\
\cline { 2 - 4 } & Phenol & Saponins & Flavonoids \\
\hline $\mathbf{E} 1(\boldsymbol{\mu g} / \mathbf{m l})$ & $\mathbf{0 . 5 9 1}$ & 0.025 & 0.009 \\
\hline $\mathbf{E} 2(\boldsymbol{\mu g} / \mathbf{m l})$ & 0.515 & 0.035 & $\mathbf{0 . 0 1 5}$ \\
\hline $\mathbf{E 3}(\boldsymbol{\mu g} / \mathbf{m l})$ & 0.556 & $\mathbf{0 . 0 4 4}$ & 0.007 \\
\hline
\end{tabular}




\section{Antibacterial activity}

Extracts of the seeds of $P$. nigrum were subjected for antibacterial study. B3 was found to be least susceptible as it showed the minimum zones of inhibition against all the three extracts (E1, E2 and E3) of P. nigrum.E1 extract was found to possess strong inhibitory activity against B1 followed by B4, but moderately inhibit the growth of B2and B5 and least effective against B3. E2 extract showed maximum ZOI against B4 followed by B5, B3, $\mathrm{B} 1$ and B2. E3 extract effectively inhibit the growth of B1 and B5 in comparison with B4, B2 and B3. In the other studies done on $P$. nigrum, methanolic extract was found have strong antibacterial activity against $E$. coli but our study showed that E1 extract of $P$. nigrum possess strong inhibitory activity against all the selected bacteria as compared to other two extracts. Abdel Gadir (2007) reported that water extract of $P$. nigrum have no activity against $E$. coli and Pseudomonas but results of our study have shown good activity of E3 extract against both the bacteria.

\section{MIC}

Different extracts of $P$. nigrum showed varied MIC values. E1 extract was found to have strong inhibitory concentration as compared to other extracts. B2 was found to be strongly inhibited by E1 extract. In E2 extract, B3 showed lowest MIC values while in E3 extract all the bacteria possess equal MIC values. In the study done by Akhtar et al., 2014, ethanol and methanol leaf extract of $P$. nigrum was found to have MIC concentration of $12.5 \mathrm{mg} / \mathrm{ml}$. The extract was considered as bacteriostatic if the MIC Index values are greater than 4 and less than 32. On the basis of the above data, all the extracts were found to have bactericidal properties.

\section{Phytochemical screening}

The E1, E2 and E3 extracts obtained from the seeds of $P$. nigrum were found to be strongly active against the selected human microbes.
Phytoconstituents have four type of bactericidal effects: 1. they inhibit cell wall synthesis 2 . They stop microbial protein and nucleic acid synthesis 3 . They disrupt microbial membrane structure and function 4 . They block metabolic pathways through inhibition of key enzymes (Latha et al., 2006 and Zulfiler et al., 2011).The various extracts of $P$. nigrum have exhibited strong inhibitory activity against the selected microbes. These microbes cause various types of food borne infections and food poisoning. Piperine, which is an alkaloid present in seeds of $P$. nigrum, was reported as a major phytochemical in the study done by Hamrapurkar et al., 2011. But in our study phenolic content was found as a major phytochemical in all the three extracts of $P$. nigrum followed by Saponins and Flavonoids. All these phytochemicals were also reported by Kumar et al., 2014 in the phytochemical screening of ethanolic extract of $P$. nigrum seeds (Tables 7-10).

In conclusion, Medicinal plants possess many phytochemicals and serve as phytotherapeutic agents for curing various diseases. They have no or negligible effects on the human body as compared to antibiotics which can provide immediate relief but also have numerous side effects. The findings of our result showed that the various extracts of $P$. nigrum have showed effectiveness as antibacterial effects. As compared to other studies, our data showed that the Ethyl acetate extract of $P$. nigrum possess strong antimicrobial activity against selected gram positive and gram negative microbes. The identified phytochemicals can be used for the formulation of herbal drugs to cure various food borne diseases as they are cost effective, environment friendly and have negligible side effects.

\section{Acknowledgement}

The authors are thankful to Authorities of Division of Life Sciences, Shri Guru Ram Rai Institute of Technology and Sciences, Dehradun, India for permitting to pursue the experiments on Antimicrobial Activity and 
Phytochemical Analysis. We declare that we have no conflict of interest.

\section{References}

Akhtar, Mohd. Sayeed, et al.,/Asian Pac J Trop Dis 2014; 4(Suppl 2): S911-S919.

Chauhan, Neha., Singh, Dolly., Paniuli, R.M., 2012 International Journal of Pharmacy and Pharmaceutical science, Vol 4, issue 2, (553-560)

Costa, E., Inês, A., Mendes-Fala A, Saavedra MJ, Mendes-Ferreira A., 2010.Potential virulence factors of Candida spp. isolated from clinical and food sources. J Hosp Infect; 75(3): 240-241.

Cowan, M.M., Clinical Microbiology Reviews, 1999, 12, 564 - 582.

Draughon, F.A., Food Technology, 2004, 58, 20 -28 .

Drummond, AJ, and RD Waigh. 2000 The development of microbial methods for phytochemical screening. Recent Res. Devel. Phytochem; 4:143-152)

Florey, HW. Chain E and Florey ME, 1989.The Antibiotic. Vol 1. Newyork: Oxford University Press.

Ganesh, P., P., Kumar, R. Suresh and Saranraj, P., 2014. Phytochemical analysis and antibacterial activity of Pepper (Piper nigrum L.) against some human pathogens, 3 (2):36-41.

Haq, I. Safety of medicinal plants. Pak J Med Res 2004; 43(4): 153-156.

Latha, M, KM, Ramkumar, Pari L, PN, Damodaran, V, Rajeshkannan and T, Suresh, 2006.

Lund, B.M., O’Brien. S.J., 2011.The occurrence and prevention of foodborne disease in vulnerable people. Foodborne Pathog Dis;
8(9): 961-973.

Mahesh, B., S. Satish, 2008. World Journal of Agricultural Sciences, 4, 839 - 843.

Md. Zulfiler AH, Siddiqua M, Nahar L, HabibMd R, Nizamuddin Hasan $\mathrm{N}$ and rana Md.S.,2011.In Vitro Antibacterial, Antifungal and Cytotoxic activity of Scoparia dulcis L. Int J Pharm Sci; 3(2): 198-203.

Phytochemical and antimicrobial study of an antidiabetic plant: Scoparia dulcis L. J Med Food; 9(3): 391-394.

Saranraj, P., S Sivasakthi, 2014.Global Journal of Pharmacology, 5, 81 - 86.

Sawhney, S.S., et al., 2011.Evaluation of bactericidal and anticancer properties of fruits of $P$. longum International Journal of Pharmacy and Pharmaceutical Sciences.

Schelz Z, Hohmann J, Molnar J., 2010.Recent advances in research of antimicrobial effects of essential oils and plant derived compounds on bacteria. In: Chattopadhyay D, editor. Ethinomedicine: A survey of complementary therapeutics. Kerala, India: Research Signpost; 179-201.

Sharma A, Bajpai VK, BaekKH., 2013.Determination of antibacterial mode of action of Allium sativum essential oil against foodborne pathogens using membrane permeability and surface characteristics parameters. J Food Safety; 33(2): 197-208.

Yang JD, Hu LB, Zhou W, Yin YF, Chen J, Shi ZQ., 2009.Lysis of Microcystis aeruginosa with extracts from Chinese medicinal herb. Int J Mol Sci; 10: 41574167.

\section{How to cite this article:}

Renu Chauhan, Ekta Chaudhary and Neha Chauhan. 2017. Investigation of Inhibitory Activity and Bioactive Compounds of Piper nigrum Seeds on Selected Human Pathogens. Int.J.Curr.Microbiol.App.Sci. 6(7): 2670-2679. doi: https://doi.org/10.20546/ijcmas.2017.607.376 